\title{
EXPERIENCE RATING AND UNEMPLOYMENT COMPENSATION
}

\author{
EMERSON P. SCHMIDT $\dagger$
}

EXPERIENCE rating has become an integral part of unemployment insurance in the United States, although a few states have not adopted it. Its proponents and opponents at times have exaggerated their own claims in support of their respective views and have erected straw men in order to discredit opposing views. Owing to the abnormal conditions since the adoption of this principle, the test of experience remains inconclusive and is destined to continue so for some time to come, especially with respect to its effect on employment regularity.

\section{Opposing Argunients}

Experience rating has been criticized on a number of points. The Social Security Board during the war frequently charged that this feature of the state laws was responsible for the "loss" of over one billion dollars to the funds, and that this might lead to the insolvency of the funds during the postwar period. Again, it has been argued that this principle has nothing to do with "social" insurance, and that it gives employers an undue interest in benefit levels and eligibility requirements. Critics frequently have argued that employers can do little to reduce unemployment, although the recent demand for industry guaranteed annual wages seems to negate this argument.

Experience rating is generally supported on three primary grounds: (1) The risk of unemployment varies widely among different industrial classifications and among employers within a specific classification; therefore, in a free-consumer-choice society the cost and price structure of each such classification and establishment (that is, commodity or service) should be made to reflect this variation. (2) To some extent the risk of unemployment is within the control of management; therefore, the tax or contribution rate levied upon each establishment should bear some direct relation to the volume of unemployment accounted for by it in order to give management a maximum incentive to minimize layoffs. (3) With one group in society (employees) receiving all the benefits, and another group (employers, in all but four states) paying the tax contributions, experience rating is highly essential to encourage a proper balance in establishing benefit levels and benefit formulas, to stimulate an employer interest in the administration of the program, and in general to act in a policing capacity to prevent the program from degenerating into a relief program.

† Director, Economic Research Department, Chamber of Commerce of the U. S. A. 


\section{Solvency of State Reserves}

Shortly after Pearl Harbor, a powerful drive was inaugurated to secure a special federal appropriation of 300 million dollars to supplement state programs during the conversion period. Dire consequences were predicted if these extra funds were not made available. Congress saw fit to ignore the appeal and, instead, encouraged prompt conversion to war production so as to get on with the war and to minimize hardship. The transition was safely made so that even Michigan, the state hardest hit by the reduction in civilian production in 1942, paid out only 72 cents in benefits for each dollar of unemployment compensation taxes collected in that year and thus actually added to its postwar reserves.

Again, in 1944, as the European war appeared to be drawing to a close, a drive was inaugurated (by the introduction of the KilgoreMurray bill) to provide federal money to supplement the funds available under the state systems. Dire predictions again were made that some of the state funds would prove insolvent and many workers would be deprived of benefits to which they were legally entitled. Under investigation, neither the Social Security Board nor other proponents of the bill would name the vulnerable states, and it appeared to the majority of Congressmen that the danger of postwar insolvency of state funds was not a probability. Yet in order to guard against the eventuality of insolvency, Congress provided for federal loans to the states under certain conditions. By the beginning of 1945, with over seven billion dollars in the reserve funds, there was general agreement that if the government, labor and employers generally cooperate in effectuating prompt reconversion to civilian production, there should be little danger of insolvency, either in the transition or the early postwar period, on the part of state funds. In the hearings in August and September, 1945, on the proposals for federal supplementary benefits the insolvency argument was not advanced.

By September, 1945, the state funds amounted to 7.3 billion dollars, a sum in excess of 9 percent of the inflated payrolls (under $\$ 3,000$ ) in peak 1944. In spite of the great increase in payrolls during the war, the unemployment compensation reserves rose from 5.7 percent, at the close of 1939, to over 9 percent by 1945. These reserves were sufficient in 1944, the Social Security Board reported, to pay 66.5 percent of all covered workers their maximum duration of benefits if that many workers were to become unemployed in the transition period. In fact, these reserves would have proved sufficient to pay benefits to 35.9 percent of all covered workers for a period of 26 weeks, at a weekly benefit rate of $1 / 20$ th of high-quarter earnings, with a minimum of $\$ 5$ for the lowest earning workers up to $\$ 25$ per week for the better paid workers. Yet it scarcely seems probable that anything like one-third 
of the covered workers will draw unemployment benefits which, in amount, would equal their benefit rights for 26 weeks during the reconversion period, unless we do a very ineffective job of reconverting to civilian production. ${ }^{1}$

These data, it needs to be emphasized, are "national" figures and tell us nothing about the solvency of the funds of individual states. Some state funds may be two to three times as solvent as some of the others. Thus, Alaska, Kentucky, North Carolina and Oregon could pay each and every covered worker (assuming 100 percent unemployment) his full benefits under the 1944 formulas of the respective state laws and still have considerable funds left. Even the "least solvent" states could pay maximum benefits to about 50 percent of the covered workers. Thus, in spite of the reduction of funds due to experience rating, there does not appear to be any great likelihood of any of the funds becoming insolvent. This argument, therefore, is likely to be little stressed in the near future.

\section{EXPERIENCE RATING AND THE BENEFit FormUlas}

During the hearings on the federal supplementation proposals (H.R. 3736 and S.1274) immediately after V-J Day, the inadequacy of the state coverage and benefit formulas was stressed. Much was made of the employer interest in experience rating as a deterrent to adequate protection. Yet, it was impossible to demonstrate that the states without experience rating had been more liberal than those with this principle in their laws.

When the "model bills" for unemployment compensation were drafted a decade ago as a guide to the state legislatures, the friends of these programs commonly proposed weekly benefits of 50 percent of regular weekly earnings, with a top limit of about $\$ 15$ per week and a duration of thirteen or fifteen weeks. Originally most states adopted this formula or one closely identical with it. Since then every state in the union, except one, has made more liberal provisions. This one state happens to be without experience rating.

Now the weekly benefit is derived in nearly all states by taking a larger fraction than $1 / 26$ th (commonly used originally) of the highest quarterly earnings (instead of average annual earnings) in the base period. The original fraction $(1 / 26$ th) would have provided a weelly benefit of about 50 percent, but now the formula provides a weekly benefit equal to about 60 percent or in some cases of about two-thirds of the average wage in the high quarter. Nearly 85 percent of the states have liberalized in this respect.

1. Since the data in the text were compiled, many states have liberalized their benefit formulas; but this additional potential drain on the reserves is offset, at least in part, by the further growth of the state funds. 
The waiting period has been reduced, the maximum weelly benefit amount has been pushed upward and the duration of benefit payments has been greatly increased as Table I indicates.

\section{TABLE I}

LiBERALIZATION OF UNEMIPLOMIENT BENEFIT ForAIULAS: 1935-1945

\begin{tabular}{|c|c|c|c|c|c|c|c|c|}
\hline \multirow[b]{2}{*}{ State } & \multicolumn{2}{|c|}{$\begin{array}{l}\text { Traiting Perits } \\
\text { (No. of Wesks) }\end{array}$} & \multicolumn{2}{|c|}{ 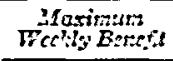 } & \multicolumn{2}{|c|}{$\begin{array}{c}\text { Maximam Diration } \\
\text { (No. of Wicsts) }\end{array}$} & \multicolumn{2}{|c|}{ 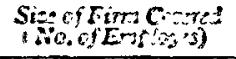 } \\
\hline & $\int_{\substack{\text { Original } \\
\text { Lar }}}$ & 1945 & 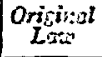 & 1945 & $\mid \begin{array}{c}\text { Oricinal } \\
\text { Lise }\end{array}$ & 1015 & $\begin{array}{c}\text { Oreiral } \\
\text { los }\end{array}$ & 1945 \\
\hline 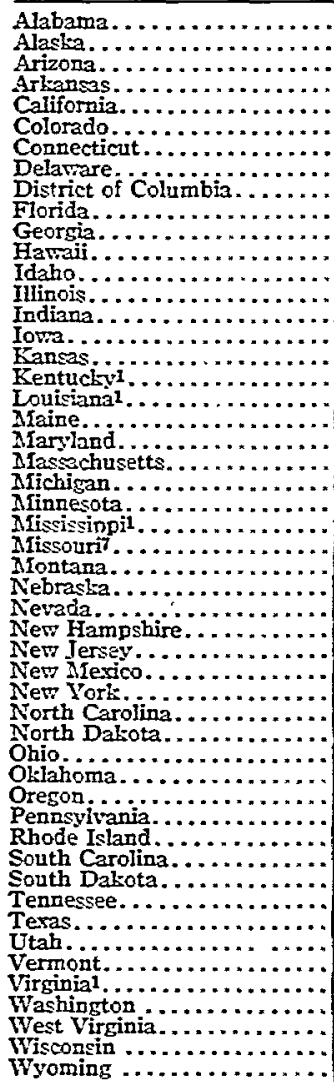 & $\begin{array}{l}3 \\
2 \\
2 \\
2 \\
42 \\
2 \\
2 \\
2 \\
3 \\
2 \\
2 \\
2 \\
3 \\
2 \\
2 \\
2 \\
2 \\
2 \\
3 \\
4 \\
2 \\
2 \\
4 \\
3 \\
2 \\
2 \\
3 \\
2 \\
2 \\
2 \\
3 \\
2 \\
2 \\
3 \\
2 \\
2 \\
3 \\
2 \\
3 \\
3 \\
3 \\
2 \\
2 \\
3 \\
2 \\
2 \\
3 \\
2 \\
2 \\
2 \\
3 \\
2 \\
\\
2 \\
2 \\
2 \\
2 \\
2 \\
2 \\
2\end{array}$ & $\begin{array}{l}1 \\
2 \\
1 \\
1 \\
1 \\
2 \\
1 \\
1 \\
1 \\
1 \\
2 \\
1 \\
2 \\
1 \\
1 \\
2 \\
1 \\
1 \\
1 \\
1 \\
0 \\
1 \\
1 \\
2 \\
2 \\
1 \\
2 \\
2 \\
1 \\
1 \\
1 \\
1 \\
1 \\
1 \\
1 \\
1 \\
1 \\
1 \\
1 \\
1 \\
1 \\
1 \\
1 \\
1 \\
1 \\
1 \\
2 \\
2\end{array}$ & $\begin{array}{l}\text { S15 } \\
\text { S10 } \\
\$ 15 \\
\$ 15 \\
\$ 15 \\
\$ 15 \\
\$ 15 \\
\$ 15 \\
\$ 15 \\
\$ 15 \\
\$ 15 \\
\$ 15 \\
\$ 15 \\
\$ 16 \\
\$ 15 \\
\$ 15 \\
\$ 15 \\
\$ 15 \\
\$ 15 \\
\$ 15 \\
\$ 15 \\
\$ 15 \\
\$ 16 \\
\$ 15 \\
\$ 15 \\
\$ 15 \\
\$ 15 \\
\$ 15 \\
\$ 15 \\
\$ 15 \\
\$ 15 \\
\$ 15 \\
\$ 15 \\
\$ 15 \\
\$ 15 \\
\$ 15 \\
\$ 15 \\
\$ 15 \\
\$ 15 \\
\$ 15 \\
\$ 15 \\
\$ 15 \\
\$ 15 \\
\$ 15 \\
\$ 15 \\
\$ 15 \\
\$ 15 \\
\$ 15 \\
\$ 15 \\
\$ 153 \\
\$ 15\end{array}$ & $\begin{array}{l}\$ 20 \\
\$ 16 \\
S 15 \\
\$ 15 \\
\$ 20 \\
\$ 15 \\
\$ 284 \\
\$ 18 \\
\$ 201 \\
\$ 15 \\
\$ 18 \\
\$ 25 \\
\$ 18 \\
\$ 20 \\
\$ 20 \\
\$ 18 \\
\$ 16 \\
\$ 16 \\
\$ 18 \\
\$ 20 \\
\$ 20 \\
\$ 21 \\
\$ 23 \\
\$ 29 \\
\$ 15 \\
\$ 13 \\
\$ 15 \\
\$ 13 \\
\$ 244 \\
\$ 20 \\
\$ 22 \\
\$ 15 \\
\$ 21 \\
\$ 20 \\
\$ 20 \\
\$ 21 \\
\$ 18 \\
\$ 18 \\
\$ 20 \\
\$ 18 \\
\$ 20 \\
\$ 15 \\
\$ 15 \\
\$ 13 \\
\$ 20 \\
\$ 15 \\
\$ 25 \\
\$ 20 \\
\$ 20 \\
\$ 20\end{array}$ & $\begin{array}{l}10 \\
16 \\
12 \\
16 \\
13 \\
13 \\
13 \\
13 \\
10 \\
16 \\
16 \\
16 \\
18 \\
16 \\
15 \\
15 \\
16 \\
15 \\
15 \\
16 \\
16 \\
16 \\
16 \\
16 \\
12 \\
12 \\
16 \\
16 \\
18 \\
16 \\
16 \\
16 \\
16 \\
16 \\
16 \\
16 \\
16 \\
15 \\
13 \\
20 \\
12 \\
16 \\
16 \\
16 \\
11 \\
14 \\
16 \\
16 \\
12 \\
13 \\
14\end{array}$ & 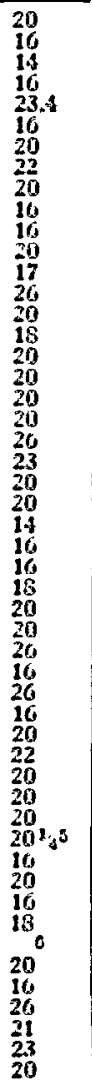 & 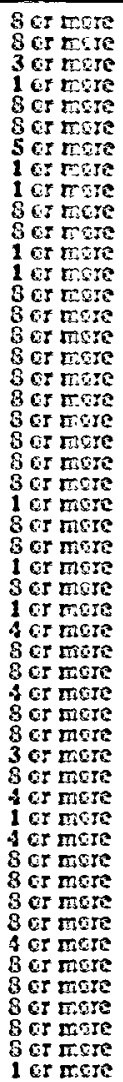 & 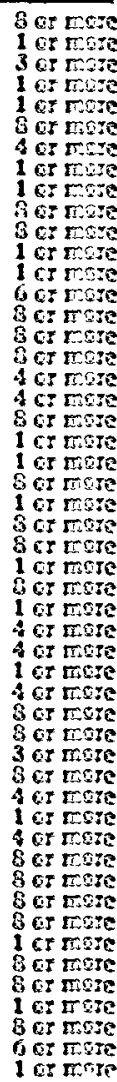 \\
\hline
\end{tabular}

INo legislative session in 1945 weeks.

Original law provided for a four weel witing period for years 1935-1939; thereafter it wes to ta three

3Ten dollar benefit if weelly salary mas $\$ 25$; $\$ 12.50$ if ealary ms $\$ 25-30$; and $\$ 15$, uf alary wos $\$ 30$ cs more.

SIncludes dependents bencfits.

cChanges in "cost of living" will affect amount of veakly bencfit and duration tut nos towal amount of benefits, $\$ 460$ in benefit year.

TLegislature has not yet acted

By August 1945, a maximum benefit of $\$ 20$ or more was provided in 28 states which included 77.5 percent of all covered workers in the country. A duration of twenty weeks or more was provided in 33 states, 
with 81 percent of all covered workers. A few states still lagged behind, but this performance in the course of a single decade does not give any substantial weight to the argument that experience rating has prevented the liberalization of the benefit formulas.

While this liberalization has taken place, some tightening of eligibility requirements and qualification features has occurred. There is wide agreement that persons covered by these programs should be substantially in the labor market, and that the millions of persons (for example, department store help during the Christmas rush) who desire work for only a few weeks in the year should not use unemployment compensation for supplementing their wages. The question of disqualifications, discussed elsewhere in this issue, ${ }^{2}$ raises many difficult problems and serious differences of opinion as to proper standards. The savings growing out of disqualifications generally have been very small. The state legislatures strengthened the disqualification provisions not in order to save the reserve funds but, rather, because nearly everywhere it was a matter of common knowledge that a few workers were taking advantage of the programs and collecting benefits to which they were not entitled. Unquestionably, these disqualifications, at times, led to some rather severe interpretations and perhaps even inequities. But any one familiar with this aspect of the program recognizes that there are no easy solutions.

Thus, it does not appear that experience rating has impeded a gradual improvement in coverage, in duration of payments and in the weekly benefit amount. Considering that these programs have been in existence for less than a decade, we can safely assert that the state legislatures on the whole have shown a commendable responsibility for their obligations, although in practice there will always be differences of opinion among students, as well as interested parties, as to the proper formulation of these programs.

\section{Financing Unemployment Compensation}

Except in four states, the entire cost of unemployment compensation is levied upon the employer and this method of financing was justified largely in terms of experience rating. If the principle of experience rating is challenged, the challenge is usually accompanied by a question as to the wisdom of levying the entire cost upon the employer. A tax upon the employer measured by payrolls is one of the worst types of taxes in terms of encouraging job expansion. The higher the wages, the higher the tax; the greater the number of workers, the greater the tax; every wage increase means a higher payroll tax; every worker added to the payroll means an extra tax. It is under experience rating coupled with effective employment stabilization that the employer's

2. See Eligibility and Disqualification, pages 117-204 supra. 
incentive to avoid the payroll tax is reduced, because the employer may qualify for a reduced or zero rate. Raising wages or adding men to the payroll is not penalized by the unemployment tax. With all the concern over adequate postwar job opportunities, the state should not levy a tax on employment unless there is some other overriding consideration. Thus; if experience rating is to be questioned, we must also raise the question of how best to finance the program.

From an economic point of view, experience rating has been criticized because during high unemployment the employer's tax rate rises and during prosperity, when the tax would least thwart enterprise and employment, the rate declines. The policy, it is argued, should be exactly reversed. ${ }^{3}$ Since this criticism of experience rating has some merit, its proponents would be well advised to discover techniques which avoid tax increases during depressions. With the large state reserves now in existence, it should be possible to develop formulas which would postpone increases in rates during the early stages of and at the bottom of depressions. Sereral states are making progress in this direction. Ten experience rating states during the recent war boom adopted special war-risk rates so that they would not have to impose unduly high rates during subsequent business recessions. Given proper encouragement, we can depend on some further significant developments in this direction.

\section{EMPLOYMENT REgULARIZATION}

Since experience rating is likely to stand or fall on its effect on greater continuity of jobs, a brief analysis in these terms needs to be made. No one believes that experience rating will stabilize the entire economy. Its proponents commonly argue that to some extent unemployment is within the control of management, and to that extent incentives can do something to minimize layoffs.

Because of the memories of the long depression unemployment in the 1930's, we are inclined frequently to overlook the fact that there are many other types or causes of unemployment: seasonal demand, seasonal supply, technological, frictional and structural, as well as casual. Before the 1930's, it was generally assumed that causes other

3. Employment Policy, representing the policy of the Churchill Britich Government, adopted flexible contribution rates (not connected with experience rating) under which the joint rates on employers and workers would fluctuate in a contra cyclical fachion from $\mathbf{5}$ to 10 shillings per week, the highest rate applying when unemployment is under 5 percent and the lowest rate applying when unemployment stands at over 11 percent. But Sir William Beveridge questions the flexing of rates in this way on practical and psychological grounds. He doubts the value of such shifts and states that it would be difficult to get the taspayers to see why, when there is less unemployment, they should be asked to pay more on behalf of some future unemployment. See Explovarent Policy (British Ministry of Reconstruction, Cmd. 6527, May 1914); Beveridge, Full Eusponsent in a Free Society (1944) 263. 
than depressions accounted for the bulk of unemployment. What the situation will be in the future is indeterminate. All would agree, however, that conscious efforts by management can minimize, and in some cases even eliminate, these causes of unemployment. The more shortrun, or controllable, unemployment is reduced, the more practical it becomes to extend the duration of unemployment compensation payments in those cases where unemployment is not eradicable.

Frequently it is asserted that certain industries-insurance, finance, public utilities and service trades as well as some non-durable consumer goods manufacturing industries-are naturally stable, and that these automatically get the benefit of experience rating without any effort toward stabilization. If one thinks of unemployment as associated only with depressions, there is of course something to this argument. But when one looks at the facts of unemployment in their comprehensive nature, this argument loses some of its validity. Thus, to take just one example, Wisconsin experience shows that 27 cents had been paid out in unemployment benefits for each dollar of contributions collected through December 31, 1940, for those employers who, as of that date, had been paying contributions for six and one-half years and whose accounts had been liable for benefit payments for four and one-half years. For the same period, the utility industry as a whole did much better than this, as shown in Table II. But the significant phenomenon to be noted is that among the utilities both as to the classifications and among the individual companies within each class, the performance was highly divergent. Thus while the electric light

\section{TABLE II}

Experience of Public Utilities in Wisconsin Through DeCeMber 31, 1940*

\begin{tabular}{|c|c|c|c|}
\hline \multirow{2}{*}{ Type of Industry } & \multicolumn{3}{|c|}{$\begin{array}{l}\text { Percentage of Premium Contributions } \\
\text { Charged as Unemployment Benefits }\end{array}$} \\
\hline & $\begin{array}{l}\text { Industry as } \\
\text { a Whole }\end{array}$ & Best Company & Worst Company \\
\hline $\begin{array}{l}\text { Taxicabs } \\
\text { Telephone Communication } \\
\text { Telegraph Communication } \\
\text { Electric Light and Power } \\
\text { Gas, Heating and Illuminat- } \\
\text { ing } \\
\text { Electric Light and Power } \\
\text { and Gas Combined } \\
\text { Water Supply Systems }\end{array}$ & $\begin{array}{l}4.7 \% \\
4.7 \\
10.8 \\
21.8 \\
11.2 \\
\\
8.8 \\
3.8\end{array}$ & $\begin{array}{c}0.0 \% \\
0.0 \\
10.4 \\
0.0 \\
10.5 \\
5.3 \\
0.0\end{array}$ & $\begin{array}{l}32.3 \% \\
41.2 \\
12.2 \\
51.9 \\
19.4 \\
23.2 \\
8.5\end{array}$ \\
\hline
\end{tabular}

*All of the employers in this table had 6.5 years of contribution experience and 4.5 years of benefit paying experience at the close of 1940 . All data from the Wisconsin Industrial Commission. 
and power companies had on the average been charged with 21.8 percent of their cumulative contributions for unemployment benefits by December 31,1940, the best company had paid no benefits and the most unstable company had paid out more than half of its cumulative contributions. Certainly this table, which could be duplicated from most, if not all, other classifications, demonstrates that unemployment is to some extent controllable.

The payroll tax savings derived through regularized employment may be substantial, especially in those cases where wage costs are a sizable portion of total costs; for example, in the laundry and cleaning business, wage and salary costs may amount to 60 percent of all costs. The savings for the 44 states which have experience ratings are indicated in Table III. These run from a minimum of $\$ 10$ to a maximum of $\$ 40$ per $\$ 1,000$ of covered payroll. These are concrete, recurring savings which are subject to accounting measurements, whereas other savings from continuous operation, while just as real, are less obvious and clear cut.

TABLE III

Potentlal Payroll Tax Savings by States

\begin{tabular}{|c|c|}
\hline Savings per $\$ I, 000$ & Number of \\
Payroll & States \\
\hline$\$ 10$ to $\$ 12$ & 5 \\
13 to 20 & 11 \\
21 to 27 & 21 \\
$271 / 2$ to 40 & 7 \\
\hline
\end{tabular}

"Tax based on first $\$ 3,000$ of payroll.

\section{Cost of Stabilization.}

Employment regularization in many instances costs money and the savings under experience rating may in some cases help offset these costs. For example, if a ski manufacturer decides that he will produce skis on a year-round basis, as several have done, he is faced with the necessity of building a warehouse, extra handling and insurance costs, higher taxes on finished inventory, and the temporary freezing of the money tied up in the finished product. In deciding whether or not to operate on a year-round basis, the employer will balance the savings against the costs of continuous operation. It is the theory of the state legislatures that in thousands of cases the potential payroll tax savings which accrue from continuous operation would tip the balance in favor of operating a plant the year around or at least more regularly.

Similarly, if a lawn mower manufacturer decides to develop a new 
slack-period product, many financial outlays are necessary. Anyone familiar with the problem of developing and establishing new products, even by well-established companies, knows that a long process of technical and market research, much trial and error, are necessary before new products can be put on a self-supporting basis.

In many instances, consumer buying habits can be changed by offering slack-period consumer discounts. Frequently, it is necessary to offer these discounts not only to consumers but also to wholesalers and retailers. All this may mean at least temporary impairment of profits and probably the incurrence of losses.

Those who have studied the operation of the experience rating in Wisconsin, where it has been in effect the longest, state that thousands of employees who formerly had highly intermittent and unsteady work now have more continuous incomes. At least a dozen Wisconsin companies, which formerly experienced an annual shut-down, operated on a year-round basis just before the war. A hardwood floor manufacturer who provided year-round employment for no one in the plant before 1934 provided continuous employment for 96 percent of the peak number of employees in 1940. A meat-packing plant which had average annual layoffs of 64 percent from 1926 to 1935 has reduced this figure to less than 10 percent in each of the years 1936 to $1945 .{ }^{4}$

\section{Cyclical Unemployment.}

To some extent, the same frame of mind and the same techniques which are eliminating short-run unemployment will mitigate cyclical or depressional unemployment. Economists have consistently deprecated overexpansion on the ground that excessive booms are likely to be followed by slumps. Under experience rating, employers expand with more caution and with better reason. This should reduce the severity of business fluctuations.

A building supply manufacturer has diversified his line to the point where now 40 percent of his raw material is fabricated into nondurable consumer goods, the demand for which remains remarkably stable regardless of general business conditions. When the next depression comes this policy of diversification will provide a cushion of employment for his people.

Several employers state that in planning research and new products they make a conscious effort to time the promotion of such new products in terms of the business cycle. Every student of business cycles knows that major depressions are attributable to many factors, and

4. The problems encountered and the regulation procedures adopted in these cases and many others are reported in To MAKE Jobs MORE STEADY AND TO MAKE MORE Steady Jobs (Webb Publishing Co., St. Paul, Minn., 1942). 
no one would argue that experience rating will eliminate depressions." However, it must be recognized that both business booms and slumps are caused by human decisions. The factors controlling these decisions will be modified to some extent now. Preliminary evidence suggests that experience rating is a new factor tending to mitigate business fluctuations. Formerly, labor costs were riewed as prime costs which tended to vary quite directly with output. Inder unemployment compensation, labor costs are to some extent converted from prime or variable costs to overhead costs. That is, labor costs are no longer completely avoidable by merely laying off the worker. For this reason employers under experience rating will have a new incentive to operate continuously since, within limits, they have to pay for labor whether they use it or not.

Another factor pointing in this same direction involves a possible reallocation of resources. It is more difficult to regularize employment in the durable goods industries (housing, motor cars, machinery, etc.) than in the non-durable consumer goods industries. Therefore, the former will pay the higher unemployment compensation tax rates to the extent to which unemployment cannot be avoided; the products of these industries will tend to rise in price. Consequently, less labor and capital resources will be devoted to producing these products, assuming some elasticity of demand, the consumption at these higher prices having decreased. This should encourage the absorption of relatively more labor in the non-durable goods industries where prices can be relatively lower and thereby encourage greater stability in the economy as a whole. How important this factor will be, in making for greater stability, is not known at this time.

Finally, in terms of the so-called acceleration principle, ${ }^{6}$ any additional stability attained in the consumer goods industries should be transferred in somewhat more than direct proportion to the durable goods industries, thus adding a further element of stability to the total economy.

\section{ConCLusion}

The period during which experience rating has been tried has been brief, as well as one characterized by great world disturbances. For these reasons, conclusive evidence on the possibilities of experience rating working in the direction intended and outlined herein is not available, but this experiment in social legislation deserves thoroughgoing cooperation on the part of all groups in society. Employers have

5. See Jajtes Arthur Estey, Business CyCles (1941).

6. See id. at $169-78$.

7. For a more complete discussion of this and the preciding point Eee E. C. Lindblom, Long-Run Considerations in Employnent Shabilization and Unemplognent Compensation (1911) 56 Q. J. Econ. 145. 
been furnished this potential tax saving as an incentive for regularizing their operations, and whether the savings feature of the laws will be retained may depend on the degree to which employers will respond by making every effort to regularize employment.

Nevertheless, it should not be overlooked that the two other arguments for the principle have independent merit: first, to allocate the necessary tax collections throughout the economy roughly in accord with the volume of unemployment attributable to each plant and industry so that the cost and price structure of each commodity will more nearly reflect the true cost without leaning on other parts of the economy; and second, to help establish some degree of equilibrium between revenue intake and benefit outgo under the rather anomalous situation wherein a small number of employers do the paying and a large number of workers get all the benefits. Because of this latter danger to the soundness of social insurance, Sir William Beveridge has been insistent upon employee contributions to the funds.

With the distribution of voting strength which prevails in a democracy, it is easy to see why the employer interest generated by experience rating in benefit levels and in benefit formulas generally, has not prevented liberalization. In fact, very considerable liberalization has already taken place, considering the youthfulness of the program, just as has been the case in workmen's compensation. On the other hand, the interest of employers, as a result of experience rating, may serve to protect the funds against unwise dissipation. 